\title{
The Response of Hepatic Transcriptome to Dietary Cholesterol in Prague Hereditary Hypercholesterolemic (PHHC) Rat
}

\author{
M. VLACHOVÁ ${ }^{1}$, M. HECZKOVÁ ${ }^{1}$, M. JIRSA ${ }^{1}$, R. POLEDNE ${ }^{1}$, J. KOVÁŘ ${ }^{1}$ \\ ${ }^{1}$ Institute for Clinical and Experimental Medicine, Prague, Czech Republic
}

Received August 11, 2014

Accepted August 19, 2014

\section{Summary}

To understand the pathogenesis of hypercholesterolemia in Prague hereditary hypercholesterolemic (PHHC) rat, we analyzed the response of hepatic transcriptome to dietary cholesterol in PHHC and control Wistar rats. Male PHHC and Wistar rats were fed chow (C), $5 \%$ fat (palm kernel oil) (CF) or $1 \%$ cholesterol $+5 \%$ fat $(\mathrm{CHOL})$ diet for three weeks. Hepatic transcriptome was analyzed using Affymetrix GeneChip arrays. No differences were found in the effect of both control diets (C and CF) on lipid metabolism and gene expression of 6500 genes. Therefore, these data were pooled for further analysis. Dietary cholesterol induced accumulation of cholesterol and triacylglycerols in the liver in both strains and hypercholesterolemia in PHHC rats. However, there were no differences in response of hepatic transcriptome to $\mathrm{CHOL}$ diet. On the other hand, several genes were found to be differently expressed between both strains independently of the diet. Two of those genes, Apof and Aldh1a7, were studied in more detail, and their role in pathogenesis of hypercholesterolemia in PHHC rats could not been corroborated. In conclusion, the hypercholesterolemia in $\mathrm{PHHC}$ rats is due to physiological response of hepatic transcriptome to dietary cholesterol in different genetic background.

\section{Key words}

Rat • Cholesterol • Diet • Genetics • Gene expression • Hypercholesterolemia

\section{Corresponding author}

M. Vlachová, Institute for Clinical and Experimental Medicine, Vídeňská 1958/9, 14021 Prague 4, Czech Republic. Fax: +420 241721 666. E-mail: miluse.vlachova@ikem.cz

\section{Introduction}

Over recent decades, our understanding of hypercholesterolemia pathogenesis has progressed substantially. However, the regulation of response of cholesterolemia to dietary cholesterol has not yet been fully clarified. It must be pointed out that the study of the effect of dietary cholesterol on cholesterolemia in rat and mouse models is complicated due to necessity to dissolve cholesterol in fat before its addition to the diet. The effects of dietary cholesterol must be then distinguished from those of the added dietary fat. Moreover, rats and mice develop hypercholesterolemia only after addition of cholic acid to the diet (Poledne and Vrána 1989).

In this respect, Prague hereditary hypercholesterolemic (PHHC) rat (Poledne 1986) presents a unique model of dietary cholesterol induced hypercholesterolemia because it does not require the addition of cholic acid and/or thyreotoxic drugs unlike all other rat models of hypercholesterolemia (Mahley and Holcombe 1977, DeLamatre and Roheim 1981, Cole et al. 1984, Cote et al. 2013). The PHHC rat was obtained through selective inbreeding of parental Wistar rats (Poledne 1986). PHHC rats have modestly increased cholesterolemia when fed chow and respond to a diet containing $2 \%$ cholesterol by a severalfold increase of cholesterolemia to concentrations comparable to those observed in hypercholesterolemic patients. Crucially, cholesterol accumulate in very low density, intermediate density and low density lipoproteins (LDL), not in high density lipoproteins (HDL) in this model (Kovar et al. 2009). However, despite considerable effort, the mechanism(s) 
responsible for hypercholesterolemia development in this model have not yet been determined. No significant differences in cholesterol absorption, LDL clearance from circulation and feedback inhibition of cholesterol synthesis have been found between PHHC and Wistar rats (Poledne 1986, Befekadu et al. 1992, Kovar et al. 2009). It has been only recently suggested that PHHC rats, when fed diet enriched with $2 \%$ of cholesterol, may not be able to upregulate enough the transcription of cholesterol 7alpha-hydroxylase gene (Cyp7a1) (Hubacek et al. 2008).

The distinct difference between PHHC and control Wistar rats in the response of cholesterolemia to dietary cholesterol indicates that PHHC rats are unable to adapt to cholesterol overload in the same way as control Wistar rats. It can be hypothesized that dietary cholesterol affects gene expression differentially in PHHC and Wistar rats. Therefore, we investigated the response of hepatic transcriptome of PHHC and control Wistar rats to dietary cholesterol using microarrays.

\section{Materials and Methods}

Rats

Male PHHC rats (bred at the Department of Experimental Medicine of the Institute for Clinical and Experimental Medicine) and control Wistar rats (AnLab, Prague, Czech Republic) weighing 260-460 g were used in the experiments. The studies on rats were conducted in conformity with the Institute for Laboratory Animal Research Guide for Care and Use of Laboratory Animals as incorporated in the guidelines and practices established by the Council for Animal Rights of the Institute for Clinical and Experimental Medicine.

\section{Diets}

The rats were fed one of the three diets: standard laboratory diet M2 (SEMED, Prague, Czech Republic) (C diet), M2 diet $+5 \%$ palm kernel oil (control fat, $\mathrm{CF}$ diet), and $\mathrm{M} 2$ diet $+5 \%$ palm kernel oil $+1 \%$ cholesterol (CHOL diet). Both PHHC and Wistar rats were kept on the above mentioned diets for three weeks.

\section{Design of the experiment}

After the 3 week feeding period, the rats $(n=6-8$ per group, six groups in total) were sacrificed and the samples of liver tissue were taken for RNA isolation for gene expression study. Four individual RNA samples per each group were used for microarray analysis; all samples from the study were used if the expression was validated by qPCR. The aliquots of liver and serum were used for quantification of cholesterol and TG.

Lipids

Cholesterol and TG in serum were measured using enzymatic kits (Roche Diagnostics). Cholesterol and TG in the liver were determined using the same method after lipid extraction from the liver homogenate (Folch et al. 1957).

\section{RNA extraction}

RNAs were produced from two liver samples of each animal. The liver samples (50-100 mg) were stored in RNAlater (Qiagen) immediately following dissection. Total RNA was isolated using TRIzol ${ }^{\circledR}$ (Invitrogen) according to the manufacturer's instructions. RNA concentration was determined spectrophotometrically and RNA integrity was confirmed on a $1 \%$ agarose gel electrophoresis after $2 \mathrm{~min}$ at $70{ }^{\circ} \mathrm{C}$. The resulting RNA samples were stored at $-80{ }^{\circ} \mathrm{C}$.

\section{Microarray analysis}

RNA samples passing quality control and microarray analysis of gene expression were processed by the Functional Genomics and Bioinformatics Core (Institute of Molecular Genetics, Academy of Sciences of the Czech Republic, v.v.i., Prague, Czech Republic) according to the manufacturer's instructions (Affymetrix).

\section{Reverse transcription}

RNA $(15 \mu \mathrm{g})$ was treated with $2 \mathrm{U}$ DNase I (Fermentas) at $37^{\circ} \mathrm{C}$ for $30 \mathrm{~min}$ followed by the addition of $2.5 \mathrm{mM}$ EDTA and incubation at $65^{\circ} \mathrm{C}$ for $30 \mathrm{~min}$ to remove trace amounts of DNA. For reverse transcription, a modified manufacturer's protocol of RevertAid $^{\mathrm{TM}}$ H Minus First Strand cDNA Synthesis Kit (Fermentas) was used. Three $\mu \mathrm{g}$ of purified RNA, $5 \mu \mathrm{M}$ oligo(dT) primer and $5 \mu \mathrm{M}$ random hexamer primer in $12 \mu \mathrm{l}$ reaction mixture were heated to $70{ }^{\circ} \mathrm{C}$ for $5 \mathrm{~min}$, then cooled on ice for $1 \mathrm{~min}$ and a reverse transcriptase reaction mix containing buffer $(50 \mathrm{mM}$ Tris- $\mathrm{HCl}$ (pH 8.3), $50 \mathrm{mM} \mathrm{KCl,} 4 \mathrm{mM} \mathrm{MgCl}_{2}, 10 \mathrm{mM} \mathrm{DTT}$ ), $20 \mathrm{U}$ RNase Inhibitor and $1 \mathrm{mM}$ dNTP mix was added. The reaction mixture was then incubated for $5 \mathrm{~min}$ at $25^{\circ} \mathrm{C}, 200 \mathrm{U}$ MuLV Reverse Transcriptase was added and incubation continued at $25^{\circ} \mathrm{C}$ for $10 \mathrm{~min}$. The reaction mix was heated to $42{ }^{\circ} \mathrm{C}$ for $60 \mathrm{~min}$, then to $70{ }^{\circ} \mathrm{C}$ for $15 \mathrm{~min}$ and placed on ice for $2 \mathrm{~min}$. 
Afterwards, RNase H (2 U) was added, followed by incubation at $37^{\circ} \mathrm{C}$ for $20 \mathrm{~min}$ and then by heating to $65^{\circ} \mathrm{C}$ for $10 \mathrm{~min}$. cDNA was purified via Qiaquick PCR Purification Kit (Qiagen) and dissolved in $30 \mu \mathrm{l}$ of DEPC water. The resulting cDNA samples were quantified spectrophotometrically at $260 \mathrm{~nm}$ and then stored at $-80^{\circ} \mathrm{C}$.

\section{Quantitative real-time PCR ( $q P C R$ )}

Reaction was performed for selected genes using a 7300 Real Time PCR System (Applied Biosystems) and TaqMan ${ }^{\circledR}$ Gene Expression Assays in combination with TaqMan ${ }^{\circledR}$ Gene Expression Master Mix, according to the manufacturer's instructions (Applied Biosystems). Twenty ng of cDNA in a $20 \mu \mathrm{l}$ reaction volume per well were used. Reactions were performed in duplicates for each sample. All results were normalized to Vars2l (the lowest standard deviation of microarray analysis of gene expression among all samples) to compensate for differences in the amount of cDNA. The relative expression levels were quantified by the delta-delta threshold cycle method with efficiency correction (Pfaffl 2001).

\section{DNA sequencing}

gDNA was extracted from peripheral leukocytes using QIAamp columns (Qiagen). The coding exons of Aldhla7 and Apof, together with the adjacent parts of the intronic sequences, were amplified by PCR with intronic oligonucleotide primers (sequences of the primers can be provided by authors on request). The amplicons were gel-purified, extracted with QIAquick spin columns (Qiagen), and used as templates for the sequencing reaction with Big DyeTerminator Kit v3.1 (Applied Biosystems) according to the manufacturer's protocol. The products were analyzed on a 3130 Genetic Analyzer (Applied Biosystems). Data were evaluated using SeqScape ${ }^{\circledR}$ Software (Applied Biosystems).

\section{Determination of Aldh1a7 activity}

The activity of aldehyde dehydrogenase family 1, subfamily A7 (Aldh1a7) was measured in cytosol fraction of liver homogenate as described by Kathmann with slight modifications (Kathmann et al. 2000). Reactions were performed at $24^{\circ} \mathrm{C}$ in $60 \mathrm{mM}$ sodium pyrophosphate buffer $(\mathrm{pH} \mathrm{8.5)}$ with $1 \mathrm{mM}$ $\mathrm{NAD}^{+}$. The initial velocities were estimated by extrapolation of differences to zero time.

\section{Statistics}

The lipid data were analyzed by ANOVA and, if ANOVA revealed any differences, then corresponding post-hoc tests were performed (GraphPad InStat). Differential gene expression analysis was performed in the $\mathrm{R}$ statistical environment ( $\mathrm{R}$ Development Core Team 2011) using the Limma package (Smyth 2005) which is a part of the Bioconductor project (Gentleman et al. 2004). Multiple testing correction was performed using the Benjamini and Hochberg method. We considered genes to be differentially expressed if the adjusted $P$ value was $<0.05$.

\section{Results}

\section{Lipids in the liver and serum}

Feeding both strains CF diet had no effect on cholesterol and TG content in the liver and or/serum (Table 1). Feeding CHOL diet resulted in accumulation of both TG and cholesterol in the liver in both PHHC and Wistar rats. The serum cholesterol concentration on CHOL diet rose in both strains, but increase was more profound in PHHC rats (Table 1). Triglyceridemia also rose on $\mathrm{CHOL}$ diet, but the increase was statistically significant only in Wistar rats.

\section{Gene expression in the liver}

Feeding both strains with the CHOL diet induced at least a twofold downregulation $(P<0.05)$ of eight genes involved in the cholesterol biosynthesis pathway and three other genes involved in the lipid metabolism (Insig, Pcsk9, and Fads) (Fig. 1A). The expression of Ldlr, Hmgcr and Cyp7al was also changed but did not fulfill the strict criteria used in the study. In either strain, no gene was upregulated on the CHOL diet, and, importantly, there were no significant differences between the response of both strains to the $\mathrm{CHOL}$ diet. Feeding both $\mathrm{PHHC}$ and Wistar rats a CF diet had no effect on the expression of any of the approximately 6500 genes expressed in the liver in comparison to the $\mathrm{C}$ diet.

When the hepatic transcriptome of both strains was compared on the same diet using the same criteria (twofold change, $P<0.05$ ), several genes were found to be expressed differently (Fig. 1B). Five genes were downregulated and four genes upregulated in the PHHC rats. The vast majority of those genes, except for Apof, have no known connection to lipoprotein metabolism. 
Table 1. Lipids in the liver and serum in PHHC and Wistar rats.

\begin{tabular}{|c|c|c|c|c|c|c|}
\hline & \multicolumn{3}{|c|}{ Wistar } & \multicolumn{3}{|c|}{ РНHC } \\
\hline & $\mathbf{C}$ & $\mathbf{C F}$ & CHOL & $\mathbf{C}$ & $\mathrm{CF}$ & CHOL \\
\hline$n$ & 8 & 8 & 8 & 6 & 6 & 7 \\
\hline \multicolumn{7}{|l|}{ Liver } \\
\hline cholesterol [umol/g] & $6.1 \pm 1.3^{\mathrm{a}}$ & $5.8 \pm 0.4^{\mathrm{a}}$ & $24.3 \pm 4.5^{b}$ & $6.0 \pm 0.7^{\mathrm{a}}$ & $5.6 \pm 1.6^{\mathrm{a}}$ & $27.6 \pm 13.1^{b}$ \\
\hline$T G[\mu \mathrm{mol} / \mathrm{g}]$ & $5.0 \pm 0.9^{\mathrm{a}}$ & $6.6 \pm 1.6^{\mathrm{a}}$ & $22.2 \pm 3.7^{b}$ & $4.8 \pm 1.1^{\mathrm{a}}$ & $5.3 \pm 1.1^{\mathrm{a}}$ & $16 \pm 8.8^{b}$ \\
\hline \multicolumn{7}{|l|}{ Serum } \\
\hline cholesterol [mmol/l] & $1.68 \pm 0.19^{\mathrm{a}}$ & $1.98 \pm 0.26^{\mathrm{a}, \mathrm{b}}$ & $2.34 \pm 0.37^{b}$ & $2.48 \pm 0.21^{\mathrm{a} * *}$ & $2.71 \pm 0.26^{\mathrm{a} * *}$ & $4.24 \pm 0.24^{\mathrm{b} * *}$ \\
\hline$T G[\mathrm{mmol} / \mathrm{l}]$ & $1.22 \pm 0.18^{\mathrm{a}}$ & $1.24 \pm 0.42^{\mathrm{a}, \mathrm{b}}$ & $1.79 \pm 0.39^{b}$ & $0.92 \pm 0.21 *$ & $0.95 \pm 0.38$ & $1.42 \pm 0.47$ \\
\hline
\end{tabular}

The results are mean $\pm \mathrm{SD} . \mathrm{a}, \mathrm{b}$ - the same letters are assigned to the groups that do not differ within a given strain $(P<0.05)$; $*, * *-P<0.05, P<0.01$ - differences between Wistar and PHHC rats on the same diet; $\mathrm{C}$ - control diet, $\mathrm{CF}-$ control fat diet, $\mathrm{CHOL}-$ cholesterol diet.

\begin{tabular}{|c|c|c|c|}
\hline $\begin{array}{c}\text { Wistar } \\
\text { Fold } \\
\end{array}$ & $\begin{array}{c}\text { Gene } \\
\text { Symbol }\end{array}$ & $\begin{array}{l}\text { PHHC } \\
\text { Fold }\end{array}$ & $\mathbf{A}$ \\
\hline \multicolumn{4}{|l|}{ cholesterol biosynthesis } \\
\hline-2.9 & Acat2 & & -3.9 \\
\hline-2.2 & Hmgcs1 & & -3.5 \\
\hline-3.7 & Idi1 & & -4.8 \\
\hline-2.6 & Fofft1 & & -2.7 \\
\hline-8.8 & Sqle & & -13.6 \\
\hline-3.8 & Cyp51 & & -4.3 \\
\hline-3.0 & $T m 7 s f 2$ & & -3.7 \\
\hline-5.0 & Sc4mol & & -6.8 \\
\hline \multicolumn{4}{|l|}{ lipoprotein metabolism } \\
\hline-4.6 & Insig1 & & -3.0 \\
\hline-2.8 & Fads1 & & -3.0 \\
\hline-2.1 & Pcsk9 & & -2.5 \\
\hline
\end{tabular}

\begin{tabular}{|c|c|c|c|}
\hline Fold & Downregulated & $\begin{array}{c}\text { Gene } \\
\text { Symbol }\end{array}$ & Upregulated \\
\hline-65.7 & & Ugt2b & \\
\hline-12.4 & & Cdh17 & \\
\hline-4.7 & & Ltc4s & \\
\hline-3.1 & & Slc6a6 & \\
\hline-2.3 & & $R t c b$ & \\
\hline 2.1 & & Cyp2d5 & \\
\hline 3.5 & & Apof & \\
\hline 8.8 & & Yc2 & \\
\hline 24.8 & & Aldh1a7 & \\
\hline
\end{tabular}

Fig. 1. A. Hepatic gene expression response in PHHC and Wistar rats to dietary cholesterol. The genes that were at least twofold downregulated on $\mathrm{CHOL}$ diet compared to both control $(C, \mathrm{CF})$ diets $(P<0.05)$ are shown. Data are presented as mean of gene expression on $\mathrm{CHOL}$ diet compared to mean of gene expression of both control diets; expression of genes on control diets is set to 1.0 . Acat2, acetyl-Coenzyme A acetyltransferase 2, NM_001006995, Hmgcs1, 3-hydroxy-3-methylglutaryl-Coenzyme A synthase 1 (soluble), NM_017268, Idi1, Isopentenyl-diphosphate delta isomerase, NM_053539, Fdft1, Farnesyl diphosphate farnesyl transferase 1, NM_019238, Sqle, Squalene monooxygenase, NM_017136, Cyp51, Cytochrome P450, subfamily 51, NM_012941, Tm7sf2, Transmembrane 7 superfamily member 2, NM_001013071, Sc4mol, sterol-C4-methyl oxidase-like, NM_080886.1, Insig1, Insulin induced gene 1, NM_022392, Fads1, Fatty acid desaturase 1, NM_053445, Pcsk9, Proprotein convertase subtilisin/kexin type 9, NM_199253. All IDs are from NCBI nucleotide database. B. Comparison of hepatic gene expression between PHHC and Wistar rats. The genes that were at least twofold down- or upregulated $(P<0.05)$ in $\mathrm{PHHC}$ rats compared to Wistar rats irrespective of the diet are shown. Data are presented as mean of gene expression on all three diets. Gene expression of Wistar rats is set to 1.0. Ugt2b, UDP glycosyltransferase 2 family, polypeptide B, NM_031533, Cdh17, Cadherin 17, NM_053977, Ltc4s, Leukotriene C4 synthase, NM_053639, S/c6a6, Solute carrier family 6 (neurotransmitter transporter, taurine), member 6, NM_017206, Rtcb, RNA 2',3'-cyclic phosphate and 5'-OH ligase, NM_207614, Cyp2d5, Cytochrome P450, family 2, subfamily d, polypeptide 5, NM_173304, Apof, Apolipoprotein F, NM_001024351, Gsta3, Glutathione S-transferase alpha 3, NM_001009920, Aldh1a7, Aldehyde dehydrogenase family 1, subfamily A7, NM_017272. All IDs are from NCBI nucleotide database. 
Table 2. Validation of microarray gene expression data using qPCR - diet influence.

\begin{tabular}{|c|c|c|c|c|c|c|c|}
\hline \multirow{2}{*}{$\begin{array}{l}\text { Gene } \\
\text { Symbol }\end{array}$} & \multicolumn{3}{|c|}{ CHOL $x$ CF } & \multicolumn{2}{|c|}{ CHOL x C } & \multicolumn{2}{|c|}{$\mathrm{CF} \times \mathrm{C}$} \\
\hline & Microarray & \multicolumn{2}{|c|}{ qPCR } & Microarray & qPCR & Microarray & qPCR \\
\hline \multicolumn{8}{|c|}{ РНHC } \\
\hline \multicolumn{8}{|c|}{ cholesterol biosynthesis } \\
\hline Acat2 & $0.251 * * *$ & 0.265 & $* * *$ & $0.269 * * *$ & $0.261 * * *$ & 1.072 & 0.985 \\
\hline $\mathrm{Hmgcr}$ & $0.482 * *$ & 0.364 & $* * *$ & $0.517 * *$ & $0.383 * * *$ & 1.073 & 1.054 \\
\hline Sqle & $0.069 * * *$ & 0.038 & $* * *$ & $0.079 * * *$ & $0.049 * * *$ & 1.140 & 1.274 \\
\hline$E b p$ & $0.696 * *$ & 0.530 & $* *$ & $0.664 * * *$ & $0.517 * *$ & 0.953 & 0.976 \\
\hline \multicolumn{8}{|c|}{ lipoprotein metabolism } \\
\hline Cyp7a1 & 3.700 & 3.083 & & $4.237 *$ & 2.901 & 1.145 & 0.941 \\
\hline Insig1 & $0.341 * *$ & 0.293 & $* * *$ & $0.323 * *$ & $0.364 * *$ & 0.946 & 1.242 \\
\hline$L d l r$ & $0.689 *$ & 0.614 & & $0.686 *$ & $0.422 * * *$ & 0.997 & 0.687 \\
\hline \multicolumn{8}{|c|}{ Wistar } \\
\hline \multicolumn{8}{|c|}{ cholesterol biosynthesis } \\
\hline Acat2 & $0.353 * * *$ & 0.298 & $* * *$ & $0.339 * * *$ & $0.291 * * *$ & 0.961 & 0.976 \\
\hline Hmgcr & 0.654 & 0.409 & $* * *$ & 0.639 & $0.444 * * *$ & 0.978 & 1.086 \\
\hline Sqle & $0.113 * * *$ & 0.059 & $* * *$ & $0.113 * * *$ & $0.074 * * *$ & 1.003 & 1.239 \\
\hline$E b p$ & $0.721 * *$ & 0.632 & $*$ & $0.652 * * *$ & $0.618 *$ & 1.000 & 0.978 \\
\hline \multicolumn{8}{|c|}{ lipoprotein metabolism } \\
\hline Cyp7a1 & 2.163 & 2.124 & & 2.275 & 2.505 & 1.052 & 1.180 \\
\hline Insig 1 & $0.238 * *$ & 0.171 & $* * *$ & $0.200 * *$ & $0.179 * * *$ & 0.842 & 1.047 \\
\hline$L d l r$ & $0.640 *$ & 0.500 & $* *$ & $0.652 *$ & $0.516 * *$ & 1.019 & 1.033 \\
\hline
\end{tabular}

Hepatic gene expression on experimental diets ( $\mathrm{CHOL}, \mathrm{CF}$ ) expressed as a mean fold of gene expression on the respective control diets $(\mathrm{CF}, \mathrm{C})$. The gene expression on control diets was always set to 1.0. * $P<0.05, * * P<0.01, * * * P<0.001$. Acat2, acetyl-Coenzyme A acetyltransferase 2, NM_001006995, Hmgcr, 3-hydroxy-3-methylglutaryl-Coenzyme A reductase, NM_013134, Sqle, Squalene monooxygenase, NM_017136, Ebp, Emopamil binding protein (sterol isomerase), NM_057137, Cyp7a1, Cytochrome P450, family 7, subfamily a, polypeptide 1, NM_012942, Insig1, Insulin induced gene 1, NM_022392, Ldlr, Low density lipoprotein receptor, NM_175762. All IDs are from NCBI Nucleotide database.

Table 3. Validation of microarray gene expression data using $\mathrm{qPCR}$ - strain influence.

\section{PHHC x Wistar}

\begin{tabular}{|c|c|c|c|c|c|c|c|c|c|c|c|c|}
\hline \multirow{3}{*}{$\begin{array}{l}\text { Gene } \\
\text { Symbol }\end{array}$} & \multicolumn{4}{|c|}{ CHOL } & \multicolumn{4}{|c|}{$\mathbf{C F}$} & \multicolumn{4}{|c|}{$\mathrm{C}$} \\
\hline & \multicolumn{2}{|c|}{ Microarray } & \multicolumn{2}{|c|}{ qPCR } & \multicolumn{2}{|c|}{ Microarray } & \multicolumn{2}{|c|}{ qPCR } & \multicolumn{2}{|c|}{ Microarray } & \multicolumn{2}{|c|}{ qPCR } \\
\hline & $1.49 \times 10^{-2}$ & $* * *$ & $4.79 \times 10^{-4}$ & $* * *$ & $1.78 \times 10^{-2}$ & $* * *$ & $9.27 \times 10^{-4}$ & $* * *$ & $1.36 \times 10^{-2}$ & $* * *$ & $5.19 \times 10^{-4}$ & $* * *$ \\
\hline$C d h 17$ & $9.69 \times 10^{-2}$ & $* *$ & $6.48 \times 10^{-2}$ & $* * *$ & $1.09 \times 10^{-1}$ & $* *$ & $8.59 \times 10^{-2}$ & $* * *$ & $5.62 \times 10^{-2}$ & $* * *$ & $5.81 \times 10^{-2}$ & $* * *$ \\
\hline$L t c 4 s$ & $1.68 \times 10^{-1}$ & $* * *$ & $1.79 \times 10^{-2}$ & $*$ & $2.53 \times 10^{-1}$ & $* * *$ & $2.18 \times 10^{-2}$ & $* *$ & $2.30 \times 10^{-1}$ & $* * *$ & $9.81 \times 10^{-2}$ & $* * *$ \\
\hline Slc6a6 & $3.90 \times 10^{-1}$ & $* *$ & $1.85 \times 10^{-1}$ & $*$ & $3.28 \times 10^{-1}$ & $* * *$ & $1.67 \times 10^{-1}$ & $*$ & $2.73 \times 10^{-1}$ & $* * *$ & $3.23 \times 10^{-1}$ & $*$ \\
\hline Apof & 3.40 & $* * *$ & 5.92 & $*$ & 3.20 & $* * *$ & 5.85 & $* *$ & 3.81 & $* * *$ & 7.62 & $*$ \\
\hline Gsta3 & 11.2 & $* * *$ & 10.2 & $* * *$ & 6.94 & $* * *$ & 9.80 & $* * *$ & 8.22 & $* * *$ & 9.76 & $* * *$ \\
\hline Aldhla 7 & 19.1 & $* * *$ & 129 & $* *$ & 30.6 & $* * *$ & 208 & $*$ & 24.8 & $* * *$ & 280 & $* * *$ \\
\hline
\end{tabular}

Hepatic gene expression in PHHC rats expressed as a mean fold of gene expression in Wistar rats that was set to 1.0 . $* P<0.05$, $* * P<0.01, * * * P<0.001$. Ugt2b, UDP glycosyltransferase 2 family, polypeptide B, NM_031533, Cdh17, Cadherin 17, NM_053977, Ltc4S, Leukotriene C4 synthase, NM_053639, S/c6a6, Solute carrier family 6 (neurotransmitter transporter, taurine), member 6, NM_017206, Apof, Apolipoprotein F, NM_001024351, Gsta3, Glutathione S-transferase alpha 3, NM_001009920, Aldh1a7, Aldehyde dehydrogenase family 1, subfamily A7, NM_017272. All IDs are from NCBI Nucleotide database. 


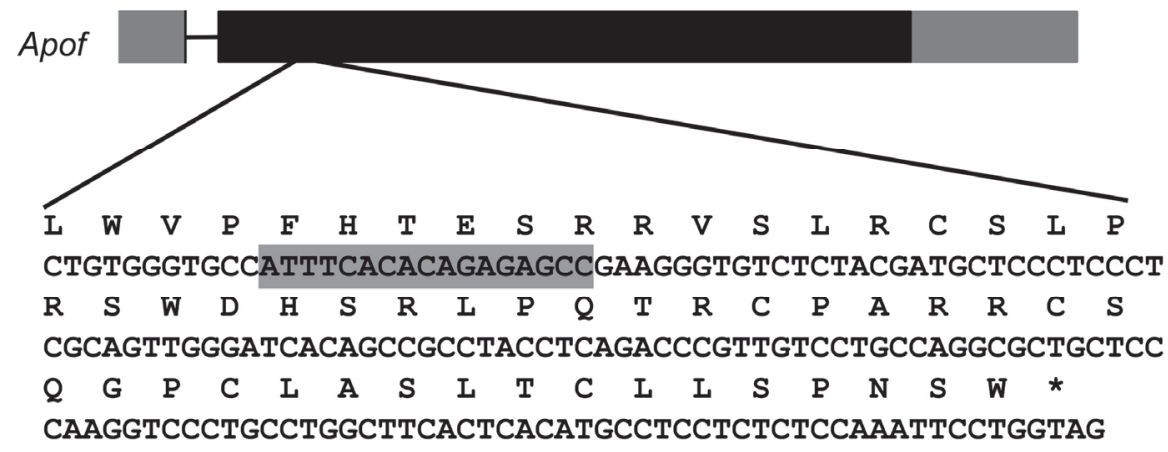

Fig. 2. Sequence of a part of second exon of Apof with 17nt insertion in $\mathrm{PHHC}$ rats. The sequence starts at coding nucleotide 82 (from translation start site). The insertion (in gray) results in a frameshift and an early stop codon. Upper line aminoacids, lower line - nucleotides.
The results of microarray gene expression were validated for 14 genes (Table 2, Table 3), the validation was carried out on RNA samples from all the animals in the study. The results of qPCR did not differ from that of microarray gene expression profiling except for three of the most prominently up- or downregulated genes (Ugt2b, Aldh1a 7, Ltc4s). The differences between both strains in the expression of these genes were found to be even more pronounced when qPCR was used for quantification.

\section{Apof sequencing}

Apof, the only gene differentially expressed in PHHC rats with a presumed role in lipoprotein metabolism, was sequenced and homozygous $17 \mathrm{nt}$ insertion in coding exon was found in all PHHC rats in the study $(\mathrm{n}=19)$. The insertion leads to a reading frame shift that should produce truncated protein (Fig. 2). The same variation of Apof was found in Wistar rats with 0.125 allele frequency $(n=24)$.

Aldehyde dehydrogenase Aldhla7 activity and sequencing of Aldhla 7 gene

Aldh1a7 specific activity was measured in both strains on $\mathrm{C}$ and $\mathrm{CHOL}$ diet to determine whether the expression of Aldhla7 (the most upregulated gene in PHHC rats independently of the diet) correlates with its activity. The Aldh1a7 activity on the $\mathrm{C}$ diet did not differ between PHHC and Wistar rats on C diet (18.8 \pm 5.1 vs 13.0 \pm 2.8 nmol NADH. min $^{-1}$.mg protein ${ }^{-1}$, respectively) and was only moderately higher in PHHC rats on CHOL diet $\left(24.4 \pm 2.4\right.$ vs $15.7 \pm 1.1$ nmol NADH. $m^{-1}{ }^{-1} \cdot \mathrm{mg}$ protein $\left.^{-1}, P<0.01\right)$. Aldhla 7 was sequenced but none mutations were detected in PHHC rats. To exclude the differences in mRNA splicing, cDNA was also sequenced. No differences between the cDNA sequences of PHHC and Wistar rats were found.

\section{Discussion}

The PHHC rat is a unique rat model because the hypercholesterolemia is induced only by feeding cholesterol without the addition of cholic acid or thyreotoxic drugs that are usually used in the other strains to affect cholesterolemia (Poledne 1986, Befekadu et al. 1992, Kovar et al. 2009). When fed $2 \%$ cholesterol diet, the PHHC rats develop hypercholesterolemia comparable to that observed in humans. Importantly, cholesterol in PHHC rats accumulates predominantly in VLDL, IDL and LDL, not in HDL (Kovar et al. 2009). Due to the profound differences between PHHC and control Wistar rats in the response of cholesterolemia to dietary cholesterol we hypothesized that there are differences between these rat strains in the response of hepatic gene expression to dietary cholesterol.

Since cholesterol must be dissolved in fat during diet preparation, we used two control diets - chow (C) and diet with fat alone (CF). Also, to minimize the effect of fat on gene expression, we used palm kernel oil that is highly saturated and does contain no cholesterol. Feeding animals CF diet had an effect on the lipids neither in serum nor the liver and, more importantly, no effect on hepatic gene expression at all. This allows us to assume that all the observed changes in hepatic transcriptome were due to the effect of dietary cholesterol because the confounding role of dietary fat was minimized.

Surprisingly, when the responses of hepatic transcriptome of PHHC and Wistar rats to dietary cholesterol were compared, no differences were found (Fig. 1A, Table 2). In both strains, most of the genes of the cholesterol biosynthetic pathway were downregulated even starting with acetyl-coenzyme A acetyltransferase 2 (Acat2). The most noticeable downregulation was observed for gene encoding squalene epoxidase $(S q l e)$ in both strains, whereas HMG-CoA reductase gene (Hmgcr) cannot be included in the list of affected genes because it did not fulfill the strict criteria we used. Such an 
observation is in agreement with findings that HMG-CoA reductase is regulated rather posttranscriptionally in rat (Leonard et al. 1994, Boone et al. 2011). Similarly to $H m g c r$, the LDL receptor gene ( $L d l r)$ and the gene for LDL receptor chaperon, Pcsk9, that modulates the number of LDL receptors on the cell surface, were downregulated only 1.5 fold, also in agreement with other findings (Horton et al. 2003, Boone et al. 2011). Insig1, a gene encoding an essential component of cholesterol feedback response, was also found to be downregulated in mice fed cholesterol (Horton et al. 2003, Engelking et al. 2005). We did not confirm the previous findings (Hubacek et al. 2008) of increased Cyp7al gene expression in Wistar rats in response to dietary cholesterol. However, we used only $1 \%$ cholesterol and palm kernel oil, not $2 \%$ cholesterol and lard in the diet and it cannot be excluded that the response of Cyp7a1 expression is affected by the quantity of dietary cholesterol and the type of fat in the diet.

Altogether, this data cannot explain why PHHC rats develop hypercholesterolemia whereas Wistar rats do not. Such a paradox can be explained by the fact that the same response of hepatic transcriptome to dietary cholesterol takes place against a different genetic background. Certainly, using the same criteria (2fold change, $P<0.05$ ), we identified several genes that do not respond to dietary cholesterol but differ between both strains independently of the diet used. Five genes were downregulated and four upregulated in PHHC rats (Fig. 1B).

The vast majority of those genes have no known connection with lipoprotein metabolism except Apof. A human ortholog of Apof encoded protein, apolipoprotein F, that is known as an inhibitor of cholesteryl ester transfer protein (CETP) in serum (Morton 1999). However, mice and rats do not have CETP and the role of the protein in these animals remains elusive. It can be speculated that apolipoprotein F could affect the transport of cholesteryl esters into VLDL during their assembly in hepatocyte. Because the upregulation may be due to the dysfunction of protein encoded by a gene, we sequenced Apof in both Wistar and PHHC rats and found that PHHC rats carry a homozygous 17 nucleotide insertion in exon 2 (Fig. 2).

To further clarify the role of apolipoprotein $\mathrm{F}$ in pathogenesis of hypercholesterolemia, we further backcrossed PHHC rats homozygous for insertion and Wistar rats homozygous for wild type variation of Apof. However, no association between the presence of the mutation and cholesterolemia response to $1 \%$ dietary cholesterol was found in offspring $(n=33)$ in $F 2$ generation (data not shown). However, hypercholesterolemia in PHHC rats is likely to be polygenic (Poledne, unpublished observation) and it cannot be excluded that the effect of one gene cannot be detectable under conditions of our experiment.

The other proteins encoded by some of the other affected genes may play a role in metabolic response to xenobiotics or oxidative stress (UDP glycosyltransferase 2, polypeptide B (Ugt2b), aldehyde dehydrogenase (Aldh1a7), cytochrome P450 CYP2D5 (Cyp2d5), and glutathion transferase (Gsta3). To ascertain the role of the most overexpressed gene in PHHC rats, Aldhla7, the activity of encoded aldehyde dehydrogenase Aldh1a7 was determined. However, the differences in the enzyme activity found between PHHC and Wistar rats are not in accordance with the gene expression differences. Although we did not find differences in the protein encoding sequence of Aldh1a7, it is possible that PHHC rats carry mutation in the regulatory sequence of the gene that results in extremely low translation rate.

Importantly, these newly identified genes and their human orthologs may become new candidate genes for human polygenic hypercholesterolemia which is the most common type of hypercholesterolemia among patients and its genetic background is not yet fully understood. It should be stressed that models like the PHHC rat can be very useful to identify new candidate genes that could be involved in pathogenesis of hypercholesterolemia. Most animal models (knock-out or transgene animals) currently in use allow us to test only the role of genes that were already identified as the candidate genes.

In conclusion, the hepatic transcriptome of PHHC rats responds to dietary cholesterol exactly in the same way as transcriptome of control Wistar rats. Such a response includes a downregulation of the genes under control of sterol regulatory element SREBP2. However, several genes are significantly up- or downregulated in PHHC rats irrespective of the diet.

\section{Conflict of Interest}

There is no conflict of interest.

\section{Acknowledgements}

The work was supported by grant No. NR9401-3 from Internal Grant Agency, Ministry of Health, Czech 
Republic and by the project for development of research organization 00023001 (IKEM, Prague, Czech Republic)
- Institutional support from Ministry of Health, Czech Republic.

\section{References}

BEFEKADU G, KOVAR J, POLEDNE R: High sensitivity of PHHC rat to dietary cholesterol. Physiol Res 41: 263-266, 1992.

BOONE LR, BROOKS PA, NIESEN MI, NESS GC: Mechanism of resistance to dietary cholesterol. $J$ Lipids 2011: 101-242, 2011.

COLE TG, KUISK I, PATSCH W, SCHONFELD G: Effects of high cholesterol diets on rat plasma lipoproteins and lipoprotein-cell interactions. J Lipid Res 25: 593-603, 1984.

COTE I, NGO SOCK ET, LEVY E, LAVOIE JM: An atherogenic diet decreases liver FXR gene expression and causes severe hepatic steatosis and hepatic cholesterol accumulation: effect of endurance training. Eur J Nutr 52: 1523-1532, 2013.

DELAMATRE JG, ROHEIM PS: Effect of cholesterol feeding on apo B and apo E concentrations and distributions in euthyroid and hypothyroid rats. J Lipid Res 22: 297-306, 1981.

ENGELKING LJ, LIANG G, HAMMER RE, TAKAISHI K, KURIYAMA H, EVERS BM, LI WP, HORTON JD, GOLDSTEIN JL, BROWN MS: Schoenheimer effect explained - feedback regulation of cholesterol synthesis in mice mediated by Insig proteins. J Clin Invest 115: 2489-2498, 2005.

FOLCH J, LEES M, SLOANE STANLEY GH: A simple method for the isolation and purification of total lipides from animal tissues. $J$ Biol Chem 226: 497-509, 1957.

GENTLEMAN RC, CAREY VJ, BATES DM, BOLSTAD B, DETTLING M, DUDOIT S, ELLIS B, GAUTIER L, GE Y, GENTRY J, HORNIK K, HOTHORN T, HUBER W, IACUS S, IRIZARRY R, LEISCH F, LI C, MAECHLER M, ROSSINI AJ, SAWITZKI G, SMITH C, SMYTH G, TIERNEY L, YANG JY, ZHANG J: Bioconductor: open software development for computational biology and bioinformatics. Genome Biol 5: R80, 2004.

HORTON JD, SHAH NA, WARRINGTON JA, ANDERSON NN, PARK SW, BROWN MS, GOLDSTEIN JL: Combined analysis of oligonucleotide microarray data from transgenic and knockout mice identifies direct SREBP target genes. Proc Natl Acad Sci USA 100: 12027-12032, 2003.

HUBACEK JA, BOBKOVA D, BOHUSLAVOVA R, POLEDNE R: Differences in expression of cholesterol 7alphahydroxylase between PHHC and Wistar rats. Folia Biol (Praha) 54: 18-23, 2008.

KATHMANN EC, NAYLOR S, LIPSKY JJ: Rat liver constitutive and phenobarbital-inducible cytosolic aldehyde dehydrogenases are highly homologous proteins that function as distinct isozymes. Biochemistry 39: 11170$11176,2000$.

KOVAR J, TONAR Z, HECZKOVA M, POLEDNE R: Prague hereditary hypercholesterolemic (PHHC) rat - a model of polygenic hypercholesterolemia. Physiol Res 58 (Suppl 2): S95-S99, 2009.

LEONARD DA, KOTARSKI MA, TESSIATORE JE, FAVATA MF, TRZASKOS JM: Post-transcriptional regulation of 3-hydroxy-3-methylglutaryl coenzyme A reductase by 3 beta-hydroxy-lanost-8-en-32-al, an intermediate in the conversion of lanosterol to cholesterol. Arch Biochem Biophys 310: 152-157, 1994.

MAHLEY RW, HOLCOMBE KS: Alterations of the plasma lipoproteins and apoproteins following cholesterol feeding in the rat. J Lipid Res 18: 314-324, 1977.

MORTON RE: Cholesteryl ester transfer protein and its plasma regulator: lipid transfer inhibitor protein. Curr Opin Lipidol 10: 321-327, 1999.

PFAFFL MW: A new mathematical model for relative quantification in real-time RT-PCR. Nucleic Acids Res 29: e45, 2001.

POLEDNE R: Effect of diet on cholesterol metabolism in the Prague hereditary hypercholesterolemic rat. In: Nutritional Effects on Cholesterol Metabolism. AC BEYNEN (ed), Transmondial, Voorthuizen, 1986, pp 9197. 
POLEDNE R, VRÁNA A: Hyperlipoproteinemia and experimental atherosclerosis. In: Methods in Animal Physiology. J DEYL, J ZICHA (eds), CRC Press, Boca Raton, 1989, pp 349-360.

R DEVELOPMENT CORE TEAM: R: a Language and Environment for Statistical Computing. R Foundation for Statistical Computing, Vienna, 2011.

SMYTH GK: Limma: linear models for microarray data. In: Bioinformatics and Computational Biology Solutions Using $R$ and Bioconductor. R GENTLEMAN, V CAREY, W HUBER, R IRIZARRY, S DUDOIT (eds), Springer New York, 2005, pp 397-420. 